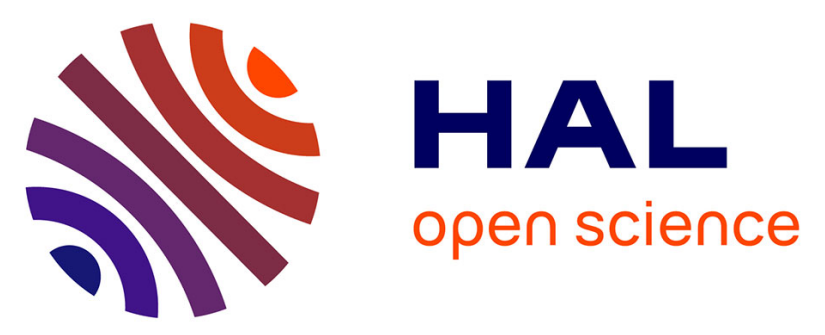

\title{
An Efficiency Fuzzy Logic Controller Power Management for Light Electric Vehicle Under Different Speed Variation
}

Nouria Nair, Ibrahim Gasbaoui, Abd Ghazouani

\section{- To cite this version:}

Nouria Nair, Ibrahim Gasbaoui, Abd Ghazouani. An Efficiency Fuzzy Logic Controller Power Management for Light Electric Vehicle Under Different Speed Variation. 6th IFIP International Conference on Computational Intelligence and Its Applications (CIIA), May 2018, Oran, Algeria. pp.106-118, 10.1007/978-3-319-89743-1_10. hal-01913918

\author{
HAL Id: hal-01913918 \\ https://hal.inria.fr/hal-01913918
}

Submitted on 7 Nov 2018

HAL is a multi-disciplinary open access archive for the deposit and dissemination of scientific research documents, whether they are published or not. The documents may come from teaching and research institutions in France or abroad, or from public or private research centers.
L'archive ouverte pluridisciplinaire HAL, est destinée au dépôt et à la diffusion de documents scientifiques de niveau recherche, publiés ou non, émanant des établissements d'enseignement et de recherche français ou étrangers, des laboratoires publics ou privés.

\section{(c)(1)}

Distributed under a Creative Commons Attribution| 4.0 International License 


\title{
An Efficiency Fuzzy Logic Controller Power Management For Light Electric Vehicle Under Different Speed Variation.
}

\author{
NAIR Nouria 1, GASBAOUI Ibrahim 2, GHAZOUANI Abd El Kader3 \\ laboratory of Smart Grids and Renewable Energies (SGRE) \\ Dpartement of Electrical Engeneering University Tahri Mohamed of Bechar, \\ BP417 Bechar(08000).Algeria \\ Email:nouia0479@gmail.com
}

\begin{abstract}
Light electric vehicle LEV autonomous present a major important problem for modern commercialized Electric Vehicle propulsion system. To improve the perfomance of LEV an efficiency fuzzy logic controller power management are proposed. The proton exchange mebran fuel hybrid system considered in this paper consists of fuel cells, lithium-ion batteries, and supercapacitors. The LEV is moving in the Algerian Saharan region, exactly in Bechar city. The aim objective of this work is to study the comportment of 2WDLEV based direct torque control supplied by differents sources of energy under diffrents speed varaiation.The performances of the proposed strategy controller give a satisfactory simulation results. The proposed control law increases the utility of LEV autonomous under several speed variations. Moreover, the future industrial's vehicle must take into considerations the hybrid power management choice into design steps. ...
\end{abstract}

Keywords: LEV, Buck Boost ,DC-DC converter,Fuzzy logic controller,PEMFC, power management

\section{Introduction}

As known that the hydrocarbons sector is the backbone of the Algerian economy witch the fall in oil and natural gas prices, has led Algeria government to adopt modest austerity measures and increased the pressure for structural and institutional economic reform. In this way the Electric Vehicles are proposed in this paper .LEV present several advantages, no emission of hydrocarbons, fumes or particles, no consumption during idling phases, batteries are recharged during deceleration phases, reduced maintenance costs and the engine is perfectly silent. The battery is capable of storing sufficient energy, offer high energy efficiency, high current discharge, and good charge acceptance from regenerative braking, high cycle time and calendar life and abuse tolerant capability It should also meet the necessary temperature and safety requisites. Nickel metal hydride $(\mathrm{NiMH})$ batteries have dominated the automotive application since 1990's due to their overall performance and best available combination of energy and power 
densities, thermal performance and cycle life. They do not need maintenance, require simple and inexpensive charging and electronic control and are made of environmentally acceptable recyclable materials. $[1,2,3]$ This paper deals with the behavior light electric vehicle (LEV) moving in the hot region under different speed variation. The LEV is equipped with two induction motors providing each one 3,3 HP. In order to minimize the ripple of current, flux and the electromagnetic torque of both induction motors an artificial neural network based direct torque control is proposed. To evaluate the performance of the proposed system, a simulation test is realized in all operating system conditions.

\section{Light Electric Vehicle description}

According to figure 1 the opposition forces acting to the light electric vehicle motion are: the rolling resistance force Ftire due to the friction of the vehicle tires on the road; the aerodynamic drag force Faero caused by the friction on the body moving through the air ; and the climbing force Fslope that depends on the road slope [1]. The total resistive force is equal to and is the sum of the resistance forces, as in (1).

$$
F_{r}=F_{\text {tire }}+F_{\text {aero }}+F_{\text {slope }}
$$

The rolling resistance force is defined by:

$$
F_{\text {tire }}=m g f_{r}
$$

The aerodynamic resistance torque is defined as follows:

$$
F_{\text {aero }}=\frac{1}{2} \rho_{a i r} A_{f} C_{d} \nu^{2}
$$

The rolling resistance force is usually modeled as:

$$
F_{\text {tire }}=m g f_{r}
$$

Where is the tire radius, $\mathrm{m}$ is the vehicle total mass, is the rolling resistance force constant,the gravity acceleration, is Air density, is the aerodynamic drag coefficient, is the frontal surface area of the vehicle, is the vehicle speed, is the road slope angle. Values for these parameters are shown in Table1. The Light Electric

Table 1. Parameters of the electric vehicle model

\begin{tabular}{lll}
\hline $\mathrm{r}$ & $0.82 \mathrm{~m} \mathrm{AF}$ & $0.80 \mathrm{~m}^{2}$ \\
\hline $\mathrm{m}$ & $400 \mathrm{Kg} \mathrm{Cd}$ & 0.32 \\
fr & 0.01 pair & $1.2 \mathrm{Kg} / \mathrm{m}^{3}$ \\
\hline
\end{tabular}

Vehicle considered in this work is two wheels drive destined to urban transportation. Two induction motors are used forlight electric vehicle. The energy source 


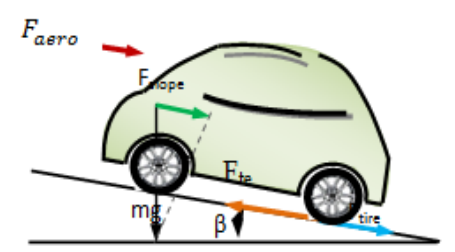

Fig. 1. The forces acting on a vehicle moving along a slope.[2]

of the electric motors comes from PEMFC hybrid system composed by Fuel cell, lithium ion battery and supercapacitor Lithium-ion battery controller by Buck boost DC-DC converter and boost converter the energy management are assured by fuzzy logic controller.[3]

\section{$3 \quad$ Fuel cell static model}

Hydrogen PEM fuel cells transform chemical energy into electrical and thermal energy by the simple chemical reaction. $[4,5,6]$

$\mathrm{H}_{2}+\frac{1}{2} \mathrm{O}_{t 2} \Longrightarrow \mathrm{H}_{2 o}+$ heat + electricalenergy(5)In order to get an electric current out of this reaction, hydrogen oxidation and oxygen reduction are separated by a membrane, which is conducting protons from the anode to the cathode side. The semi reactions on both electrodes are:

$$
\begin{gathered}
\mathrm{H}_{2} \Longrightarrow 2 \mathrm{H}+2 e^{-} \text {anode } \\
\mathrm{O}_{2}+4 e^{-} \Longrightarrow 2 \mathrm{O}_{2}^{-} \text {cathode }
\end{gathered}
$$

While the protons are transported through the membrane, electrons are carried by an electric circuit in which their energy can be used. Modelling of fuel cells is getting more and more important as powerful fuel cell stacks are getting available and have to be integrated into power systems. In[7] Jeferson M. Corra introduced a model for the PEMFC. The model is based on simulating the relationship between output voltage and partial pressure of hydrogen, oxygen, and currant. The output voltage of a single cell can be defined as the result of the following expression,figure 2 shows the basic proton exchange membrane fuel cell scheme:

$$
V_{F C}=E_{N e n s t}-V_{a c t}-V_{o h m}-V_{c o n}
$$




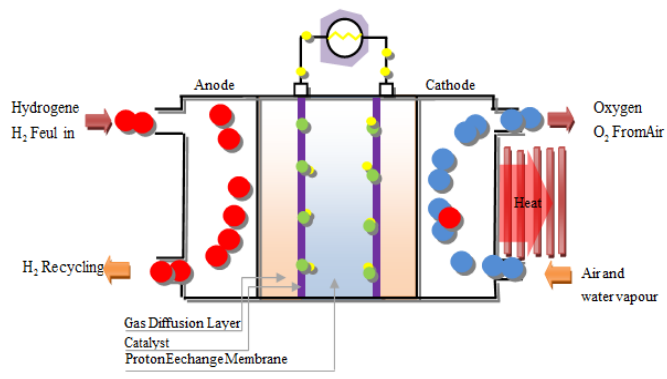

Fig. 2. Basic Proton exchange membrane fuel cell scheme.[3,6]

\section{Direct torque control strategy based space vector modulation (SVM-DTC)}

In this technique there are two proportional integral (PI) type controllers instead of hysteresis band regulating the torque and the magnitude of flux. Refereeing to figure 3, two proportional integral (PI) type controllers regulate the flux amplitude and the torque, respectively. Therefore, both the torque and the magnitude of flux are under control, thereby generating the voltage command for inverter control. Noting that no decoupling mechanism is required as the flux magnitude and the torque can be regulated by the PI controllers. Due to the structure of the inverter, the DC bus voltage is fixed, therefore the speed of voltage space vectors are not controllable, but we can adjust the speed by means of inserting the zero voltage vectors to control the electromagnetic torque generated by the induction motor. The selection of vectors is also changed. It is not based on the region of the flux linkage, but on the error vector between the expected and the estimated flux linkage $[8,9,10,11]$. The induction motor stator flux can be estimated by :

$$
\begin{gathered}
\Phi_{d s}=\int_{0}^{t}\left(V_{d s}-R_{s} i_{d s}\right) d t \\
\Phi_{q s}=\int_{0}^{t}\left(V_{q s}-R_{s} i_{q s}\right) d t \\
\left|\Phi_{s}\right|=\sqrt{\Phi_{d_{s}^{2}}^{2}+\Phi_{q s}^{2}} \\
\theta_{s}=\tan ^{-1}\left(\frac{\Phi_{q s}}{\Phi_{d s}}\right)
\end{gathered}
$$

The electromagnetic torque Tem can be written as follow:

$$
T_{e m}=\frac{3}{2} p\left(\Phi_{d s} i_{q s}-\Phi_{q s} i_{d s}\right)
$$


The SVM principle is based on the switching between two adjacent active vectors and two zero vectors during one switching period. It uses the space vector concept to compute the duty cycle of the switches.

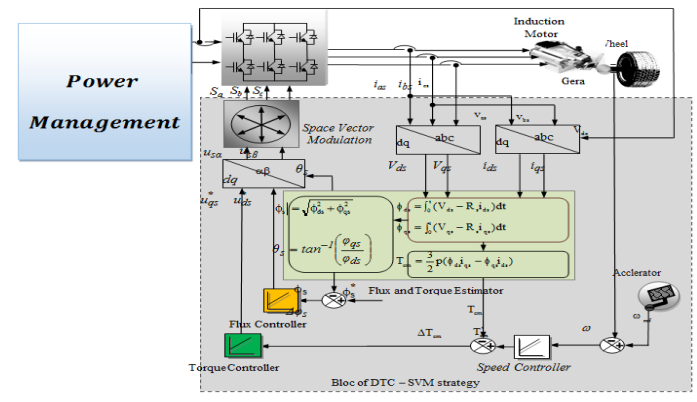

Fig. 3. Bloc diagram for DTC strategy based space vector modulation.[2]

\section{$5 \quad$ Energy management strategies}

The energy management system is required to ensure the following:

-low hydrogen consumption;

-high overall system efciency;

-narrow scope of the battery/supercapacitor SOC;

-long life cycle.[11]

This is achieved by controlling the power response of each energy source with load demand through their associated con- verters, using a given EMS. For this paper, fuzzy logic conbytroller state-of-the-art EMSs are considered and designed based on the requirements given in table 2 .

\section{The rule based fuzzy logic strategy}

This scheme has a faster response to load change compared to state machine control and is more robust to measurement imprecisions. The fuel cell power is obtained based on the load power and SOC membership functions and the set of if-then rules. The scheme is shown in Figure 4. The design is made following an approach similar [12] to where trapezoidal membership functions are used as shown in Figure 5,6,7.The fuzzy logic rules are derived from the state machine control decisions as shown in table 2. The Mamdanis fuzzy inference approach is used along with the centroid method for defuzzication. The fuzzy logic control surface obtained is shown in Figure 8. The linguistic variables are defines as $\mathrm{H}, \mathrm{M}, \mathrm{L}, \mathrm{VL}$ meaning high, meduim, low and very low respectively, and the membership function is illustrated in the Figures 5,6,7. Using the settings given 


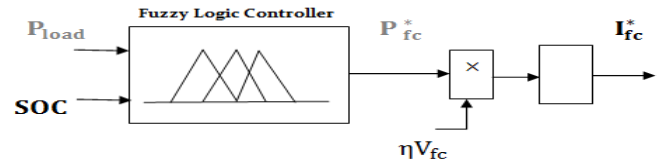

Fig. 4. Basic fuzzy logic controller

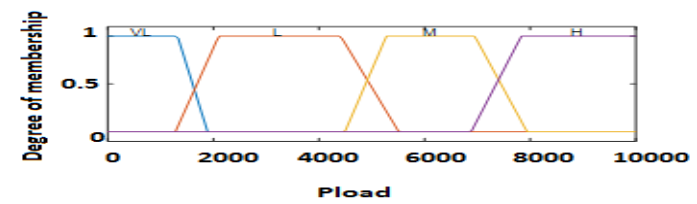

Fig. 5. The Membership function of input Pload

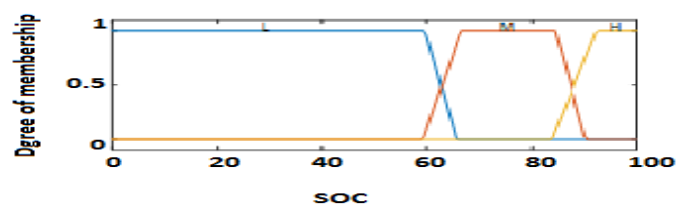

Fig. 6. The Membership function of input SOC

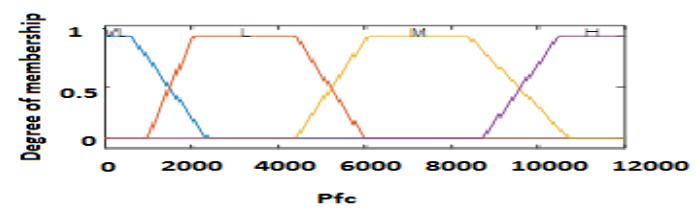

Fig. 7. The Membership function of output Pfc

in Table 2 the fuzzy controllers were obtained and are given in figures 8.[10]. The rule based fuzzy logics strategy is implemented in SPS using a Simulink Fuzzy Logic Controller block from the Fuzzy logic Toolbox. The design of this Fuzzy Logic controller is made with the help of the FIS (Fuzzy Inference System) Editor GUI (Graphical user interface) tool of Matlab. This tool allows to create input/output variables, membership functions and rules in a very convenient fashion, without having to develop complicated fuzzy logic system code. The twelve Fuzzy tuning rules are descript in Table 2 below.

\section{Simulation Results}

In order to characterize the behavior of the driving wheel system, simulations were carried out using the model in Figure 9. The following results were simulated in MATLAB/SIMULINK, and its divided into two phases, the first one represent 
Table 2. Fuzzy logic Rules

\begin{tabular}{|c|c|}
\hline & Fuzzy logic Rules \\
\hline & If (Pload is $\mathrm{VL}$ ) and ( $\mathrm{SOC}$ is $\mathrm{H})$ then ( $\mathrm{Pfc}$ is $\mathrm{VL}$ ) \\
\hline 2 & If (Pload is $\mathrm{L})$ and ( $\mathrm{SOC}$ is $\mathrm{H})$ then $(\mathrm{Pfc}$ is $\mathrm{L})$ \\
\hline 3 & If If (Pload is $\mathrm{M})$ and ( $\mathrm{SOC}$ is $\mathrm{H})$ then ( $\mathrm{Pfc}$ is $\mathrm{M}$ ) \\
\hline 4 & If If (Pload is $\mathrm{H})$ and ( $\mathrm{SOC}$ is $\mathrm{H})$ then ( $\mathrm{Pfc}$ is $\mathrm{H})$ \\
\hline 5 & If If (Pload is VL) and (SOC is $\mathrm{M})$ then ( $\mathrm{Pfc}$ is $\mathrm{VL}$ ) \\
\hline 6 & If If (Pload is $\mathrm{L})$ and ( $\mathrm{SOC}$ is $\mathrm{M})$ then ( $\mathrm{Pfc}$ is $\mathrm{L}$ ) \\
\hline 7 & If If (Pload is $\mathrm{M}$ ) and ( $\mathrm{SOC}$ is $\mathrm{M})$ then ( $\mathrm{Pfc}$ is $\mathrm{M}$ ) \\
\hline & If If (Pload is $\mathrm{H})$ and (SOC is M) then ( $\mathrm{Pfc}$ is $\mathrm{H})$ \\
\hline & If If (Pload is VL) and ( $\mathrm{SOC}$ is $\mathrm{L})$ then ( $\mathrm{Pfc}$ is $\mathrm{L})$ \\
\hline & If If (Pload is $\mathrm{L})$ and ( $\mathrm{SOC}$ is $\mathrm{L})$ then ( $\mathrm{Pfc}$ is $\mathrm{M})$ \\
\hline & If If (Pload is $\mathrm{M})$ and ( $\mathrm{SOC}$ is $\mathrm{L})$ then ( $\mathrm{Pfc}$ is $\mathrm{H})$ \\
\hline & If If (Pload is $\mathrm{H})$ and ( $\mathrm{SOC}$ is $\mathrm{L})$ then ( $\mathrm{Pfc}$ is $\mathrm{H})$ \\
\hline
\end{tabular}

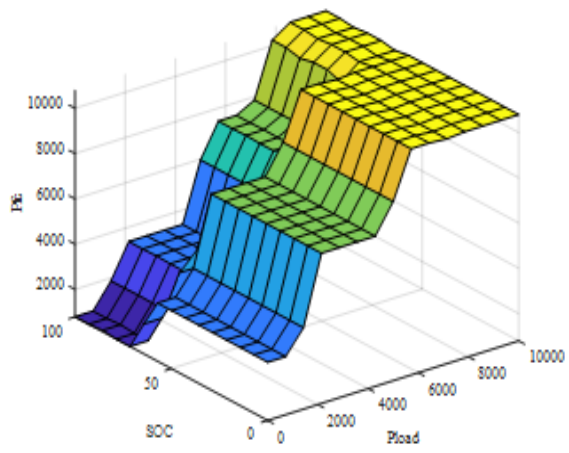

Fig. 8. Fuzzy logic control surface.

a performance test of 2WDES controlled by DTC-SVM in various speed and second phase shows the behavior of 2WDES energy management schemes based fuzzy logic controller for The fuel-cell hybrid system during the different scenarios consideration. The fuel-cell hybrid system are composed by fuel cells, lithium-ion batteries, and supercapacitor.

\subsection{Direct torque control scheme with space vector modulation.}

The topology studied in this present work consists of five phases: the first one represent straight road with $40 \mathrm{Km} / \mathrm{h}$, the second phase symbolize straight road with $80 \mathrm{~km} / \mathrm{h}$, the tired phase a 2 WDES is moving up the slopped road of $10 \%$ under $80 \mathrm{~km} / \mathrm{h}$, fourth cases represent directly road and finally the proposed system are moving the inverse sloped road with $80 \mathrm{Km} / \mathrm{h}$, the speed road constraints are described in the Table 3.

Table 4 explains the variation of phase current and driving force respectively.In 


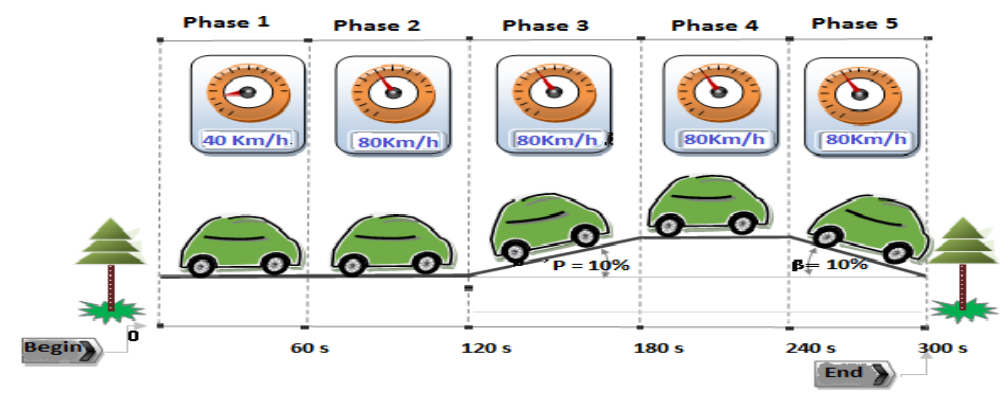

Fig. 9. Specify driving route topology

Table 3. Specified driving route topology

\begin{tabular}{lll}
\hline Phases & Event information & Vehicle Speed $[\mathrm{km} / \mathrm{h}]$ \\
\hline Phase 1 Straight road & 40 \\
Phase 2 Straight road & 80 \\
Phase 3 climbing a slope 10\% & 80 \\
Phase 4 Straight road & 80 \\
Phase 5 climbing a inverse slope 10\% 80 \\
\hline
\end{tabular}

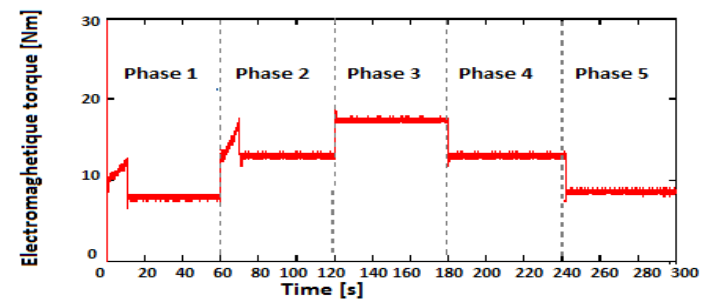

Fig. 10. Variation of electromagnetic torque in different phases.

the first step and to reach $80 \mathrm{~km} / \mathrm{h}$ The $2 \mathrm{WDEV}$ demand a current of $20.43 \mathrm{~A}$ for each motor which explained with driving force of $128.70 \mathrm{~N}$. The third phases explain the effect of sloped road. The driving wheels forces increase and the current demand undergo double of the current braking phases the PEMFC use $41.87 \%$ of his power to satisfy the motorization demand under the slopped road condition which can interpreted physically the augmentation of the globally vehicle resistive torque illustrate in figure10.In the other hand the linear speeds of the two induction motors stay the same and the road drop does not influence the torque control of each wheels. In the fifth phases the current and driving forces demand decrees by means that the vehicle is in recharging phases which explained with the decreasing of current demand and developed driving forces shown in figure10.The results are listed in Table 4. According to the formulas (1), (2),(3) and (4) and Table 5, the variation of vehicle torques in different cases as depicted in Figure 12, the vehicle resistive torque was 127.60 N.m in 
Table 4. Values of phase current driving force of the right motor in different phases.

\begin{tabular}{llllll}
\hline Phases & Phase & Phase & Phase 3 & Phase & Phase 5 \\
\hline Current of the right motor $[\mathrm{A}]$ & 20.43 & 20.43 & 20.43 & 20.43 & 18.50 \\
Driving force of the right motor $[\mathrm{N}]$ & 128.70 & 128.70 & 161.10 & 128.70 & 96.28 \\
\hline
\end{tabular}

the first case (curved road) ,in the sloped road (phases 3), the front and rear driving wheels develop more and more efforts to satisfy the traction chain demand which impose an resistive torque equal to 168.00 N.m .In the last phase (breaking phase ) the resistive vehicle torque are equal to $86.00 \mathrm{~N} . \mathrm{m}$.The result prove that the traction chain under sloped road demand develop the double effort comparing with the breaking phase cases by means that the vehicle needs the half of its energy in the inverse slop phase's compared with the sloped road one's as it specified in Table 4 and Figure 14.

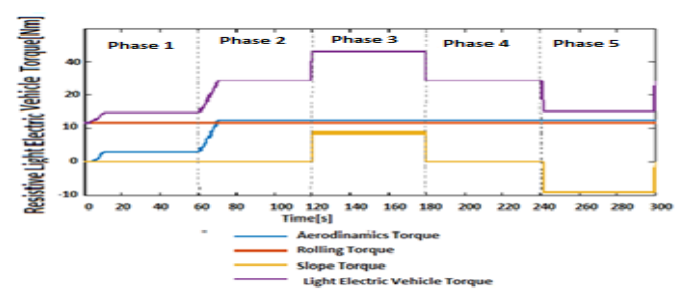

Fig. 11. Evaluation of resistive vehicle torque in different phases.

Table 5. Variation of vehicle torque in different Phases.

\begin{tabular}{|c|c|c|c|c|}
\hline Phases & Phase 1 Phas & Phase & Phase & Phase \\
\hline the Vehicle $r$ & 127.60 & 168.40 & 127.60 & 86.00 \\
\hline with nominal motor torque of $392.46 \mathrm{Nm}$ & $32.51 \%$ & $42.90 \%$ & $32.51 \%$ & $24.34 \%$ \\
\hline
\end{tabular}

\subsection{Fuzzy logic controller power management for 2WDES}

The PEMFC hybrid system considered in this paper consists of PEMFC, lithiumion batteries, and supercapacitors must be able to supply sufficient power to the 2WDES in different phases, which means that the peak power of the PEM fuel cell supply must be greater than or at least equal to the peak power of the two electric motors. The PEMFC must store sufficient energy to maintain their Fuel 
at a reasonable level during driving, Figure 12, describe the evaluation of power for different sources during all trajectory.

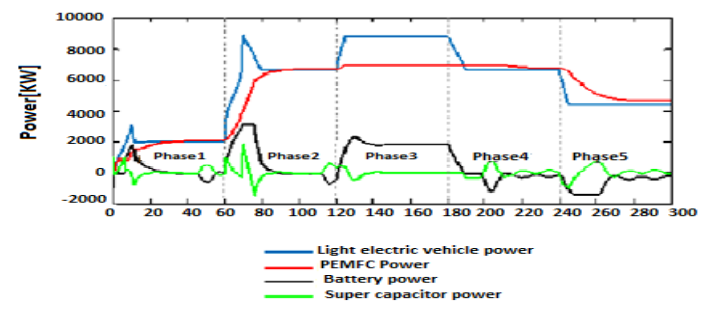

Fig. 12. Evaluation of power for different sources Durant all trajectory.

It is very interesting to describe the power of different sources distribution in the electrical traction under several speed variation as it described in Figure 12. The PEMFC power provides about $2.07 \mathrm{Kw}$ in the first phase in order to reach the electronic differential reference speed of $40 \mathrm{Km} / \mathrm{h}$. At t $=70 \mathrm{~s}$. . At this time the extra load power required is instantly supplied by the supercapacitor due to its fast dynamics, while the fuel cell power increases slowly. In the second phases and exactly at $\mathrm{t}=70 \mathrm{~s}$, the peak of $2 \mathrm{WDEC}$ is assured by the lithium ion battery power, in the third phases (sloped phase's) the power demande are assured by the PEMFC power provides about $8.80 \mathrm{Kw}$ and battery power $(1.8 \mathrm{Kw})$.In the fourth phases the globally nominal power PEMFC $(7.02 \mathrm{Kw})$.the power of the battery is negative that mean the lithium ion is recharged via PEMFC and the supercapoacitor provide their power to satisfied the power demande.And finaly the PEMFC power is about $4.7 \mathrm{Kw}$. Of the demanded power battery increased about $13.00 \mathrm{Kw}$ that present $16.10 \%$ produced power is equal to $6.70 \mathrm{Kw}$ under inverse slopped road state. The used PEMFC produced power depend only on the electronic differential consign by means the sloped/inverse slop driver state which can be explained by the PEMFC current of Figure 15.

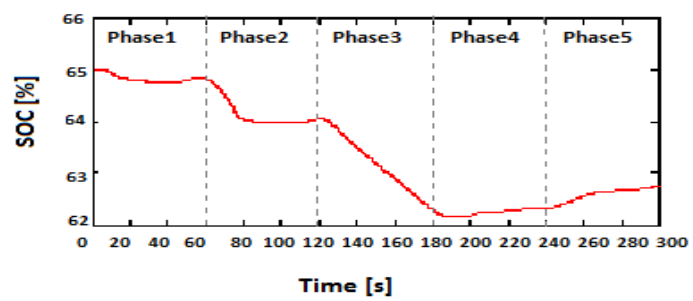

Fig. 13. Variation of state of charge during all trajectory.

Figure 13 explains how SOC in the Lithium-ion battery changes during the driv- 
ing cycle, it seems that the SOC decreases rapidly at the third phases (sloped road $10 \%$ ), At $\mathrm{t}=192 \mathrm{~s}$, the SOC battery becomes less than $62.18 \%$ (it was initialized at $65 \%$ at the beginning of the simulation), so the battery must be recharged. The PEMFC and super capacitor shares its power between the lithium ion battery and the 2WDES you can see that the battery power becomes negative. This means that the battery receives power from the PEMFC and super capacitor.

Table 6. State of charge in different scenarios.

\begin{tabular}{lllllll}
\hline Time [s] & 0 & 60 & 120 & 180 & 240 & 300 \\
\hline State of charge[\%] & 65 & 64.73 & 64.32 & 64.37 & 62.32 & 62.73 \\
\hline
\end{tabular}

The relationship between SOC and time in different phases are defined by the flowing linear fitting formula:

$$
\begin{aligned}
& \text { SOC }[\%]=-3.6864 e^{-21} t^{10}+4.7848 e^{-186} t^{9}-2.4794 e^{-15} t^{8} \\
& +6.3089 \mathrm{e}^{-13} t^{7}-7.0985 e^{-11} t^{6}-9.6612 e^{-10} t^{5} \\
& -1.1196 \mathrm{e}^{-6} t^{4}-0.0001144 t^{3}+0.0047067 t^{2}-0.078718 t+65.241(14)
\end{aligned}
$$$$
\text { FulConsumption }[g]=-2.0377 e-06 t^{3}+0.0010537 t^{2}--0.031357 t+0.40936
$$

\section{Conclusion}

The vehicle energy policy outlined in this paper has demonstrated that the PEMFC behavior controlled by buck boost DC-DC converter for utility $2 \mathrm{WDEV}$ which utilize two rear and front deriving wheel for motion can be improved using direct torque control strategy based on space vector modulation when the PEMFC developed power depend on the speed reference of the driver. The several topologies road do not affect the performances of the buck boost DC-DC converter output voltage and the control strategy gives good dynamic characteristics of the $2 \mathrm{WDEV}$ propulsion system. This paper proposes novel fitting formulas which give the relationship between the PEMFC voltage and distance traveled and others formulas that give more efficiency to different propulsion systems paths. This study enables the prediction of PEMFC dynamic behavior under different road topologies conditions, which is considered as a foundation for control and power management for $2 \mathrm{WDEV}$. 


\section{References}

1. A. Brahim Gasbaoui, Abdelkader Chaker, Abdellah Laoufi, Boumedine Allaoua, Abdelfatah Nasri The Efficiency of Direct Torque Control for Electric Vehicle Behavior Improvement SERBIAN JOURNAL OF ELECTRICAL ENGINEERING Vol.8, No. 2, May 2011, 127-146.

2. B. Brahim Gasbaoui, Abdelfatah Nasri, Abdellah Laoufi and Youssef Mouloudi ,4 WD Urban Electric Vehicle Motion Studies Based on MIMO Fuzzy Logic Speed Controller, Faculty of the sciences and technology, Bechar University International Journal of Control and Automation Vol.6, No.1, February, 2013.

3. C. Gasbaoui Brahim ,Commande direct du couple dun vehicule electrique deux roues motrices. These 2012 ,p47, p97, p99.

4. D. W. Colella, Cleaning the air with fuel cell vehicles : net impact on emissions and energy use of replacing conventional internal combustion engine vehicles with hydrogen fuel cell vehicles. The First European Fuel Cell Technology and Applications Conference,ASME,2005.

5. E. D. Boettner. G. Paganelli. Y.G. Guezennec. G. Rizzoni. M.J. Moran. Proton exchange membrane fuel cell system model for automotive vehicle simulation and control. ASME Journal of Energy Resources Technology, 2002.

6. F. J.H. Hirschenhofer. D.B. Stauffer. R.R. Engleman. M.G. Klett. Fuel Cell Handbook, Seventh Edition. FETC, 2004.

7. G. Jeferson M. Corra, Simulation of fuel-cell stacks using a computer-controlled power rectifier with the purposes of actual high-power injection applications; IEEE Transactions on Industry Applications ( Volume: 39, Issue: 4, July-Aug. 2003 )

8. H. M. Jafarboland H. Abootorabi Zarchi J.Efficiency-Optimized Variable Structure Direct Torque Control for Synchronous Reluctance Motor Drives Electrical Systems 8-1 (2012): 95-107

9. I. Motors Zhifeng Zhang, Renyuan Tang, Baodong Bai, and Dexin Xie, Novel Direct Torque Control Based on Space Vector Modulation With Adaptive Stator Flux Observer for Induction ,IEEE TRANSACTIONS ON MAGNETICS, VOL. 46, NO. 8, AUGUST 2010

10. J. S. Belkacem, F. Naceri and R. Abdessemed, Improvement in DTC-SVM of AC Drives Using a New Robust Adaptive Control Algorithm ; Accepted for Publication at the International Journal of Control Automation and System, IJCAS, vol.9, no. 2,2011.

11. K.Louis-A, A Comparative Study of Energy Management Schemes for a FuelCell Hybrid Emergency Power System of More-Electric Aircraft Souleman Njoya Motapon, Member, IEEE, . Dessaint, Fellow, IEEE, and Kamal Al-Haddad, Fellow, IEEE TRANSACTIONS ON INDUSTRIAL ELECTRONICS, VOL. 61, NO. 3, MARCH 2014

12. L.S. Caux, W. Hankache, M. Fadel, and D. Hissel, On-line fuzzy energy management for hybrid fuel cell systems, Int. J. Hydrogen Energy, vol. 35, no. 5, pp. 21342143, Mar. 2010. 